\title{
Crustacean Decapod Assemblage Associated with Seagrass (Zostera marina) Beds in Southern Waters of Korea
}

\author{
Joo Myun Park ${ }^{1, *}$, Seok Nam Kwak ${ }^{2}$ and Ralf Riedel ${ }^{3}$ \\ 1 Dokdo Research Center, East Sea Research Institute, Korea Institute of Ocean Science \& Technology, Uljin \\ 36315, Republic of Korea; joomyun.park@kiost.ac.kr \\ 2 Environ-Ecological Engineering Institute Co. Ltd, Busan 48280, Republic of Korea; seoknam@eeei.kr \\ 3 S\&R Consultancy, Ocean Springs, Mississippi, United States; ralf.riedel@usm.edu \\ * Correspondence: joomyun.park@kiost.ac.kr; Tel.: +82-54-780-5344
}

\begin{abstract}
Decapod assemblages in Zostera marina beds from two bays adjacent to unvegetated habitats were investigated to assess their influence on decapod assemblages. Thirty-eight decapod species belonging to 4 taxa were collected using a small beam trawl at four habitat types from two different locations off the coast of Namhae Island, southern Korea. Dominant decapod taxon at all habitats was the caridean shrimps, with Eualus leptognathus, Heptacarpus pandaloides, Latreutes anoplonyx, La. laminirostris and Palaemon macrodactylus being the most abundant caridean species. Crabs were characterized by the highest biomass, but moderate species richness and abundance. Penaeoids and sergestoids shrimps only accounted for $<1 \%$ of the total decapod abundance. The number of species, their abundance, and the diversity of decapod assemblages varied greatly by habitat type, season, and diel patterns. Species number and abundance peaked in seagrass beds of southern exposed bays during the autumn, and were lowest in unvegetated habitats during the summer months. Diel decapod species and catch rates were higher at night. Dense seagrass vegetation and nighttime supported greater decapod species richness and higher mean densities, but not diversity. Multivariate analyses revealed that habitat type and season significantly affected the structure of decapod assemblages, but diel patterns had a minor influence. Among decapod species, Pa. macrodactylus and Pugettia quadridens characterized the decapod assemblages in seagrass beds at the northern semi-closed bay, while Telmessus acutidens, Crangon affinis, Cr. hakodatei, Charybdis japonica and Portunus sanguinolentus were significantly associated with both vegetated and unvegetated habitats at the southern exposed bay, with the former two species more abundant during winter and spring.
\end{abstract}

Keywords: decapod assemblage; Zostera marina; Namhae Island; seagrass vegetation; day/night change

\section{Introduction}

Seagrass beds are one of the most productive marine habitats common in estuarine and shallow marine coastal ecosystems throughout the world $[1,2]$. Among seagrass species, Zostera marina is the most common in temperate coastal areas of the Western Pacific, providing shelter for many marine animals, especially their juveniles [3-6]. Seagrass meadows' high structural complexity also provides refuge from predators [7-9] and allows coexistence of species occupying different ecological niches [10]. As a further benefit, seagrass beds provide feeding and nursery grounds for many commercial and recreational vertebrate and invertebrate species [4,11-13]. 
Previous studies on seagrass faunal assemblages have shown that vegetated seagrass meadows have a consistently higher diversity and abundance of vertebrates and invertebrates than other coastal habitats $[10,14]$. In addition, because seagrasses stabilize sediments from tidal currents and wave action [15,16], they provide suitable habitat for benthic invertebrates $[17,18]$.

Habitat structure complexity has often been associated with biodiversity (e.g. [19]), with a more complex habitat providing a wider range of niches and thus a higher number of resident species occupying that habitat [20-23]. The diversity of decapod assemblages, similarly, have been shown to be higher in seagrass beds compared with non-vegetated habitats. Bloomfield and Gillanders [24] reported similar faunal assemblages at seagrass and non-vegetated habitats in southern Australia, but the loss of vegetated habitats could result in a higher loss rate of species richness and abundance at seagrass assemblages. More recently, Park and Kwak [25] showed that seagrass beds adjacent to both tidal flats and rocky shores supported greater decapod abundances and diversities than adjacent unvegetated habitats. Large seagrass beds often contribute to greater diversity and abundance of faunal assemblages than in adjacent non-vegetated habitats [25-27], due possibly to the high abundances of eelgrass residents [28]. Comparative studies of decapod assemblages between vegetated and unvegetated seagrass habitats have shown unvegetated habitats dominated by fewer species [25], with considerable diel and seasonal variations in abundance and assemblage structure (e.g. [25,29-31]).

Large seagrass beds are found along the shoreline of Namhae Island, southern Korea, which provide habitat for a variety of invertebrates and small fish [32-34]. Although a number of studies comparing fish and decapod assemblages in seagrass meadows have been conducted globally [28,29,35-39], few such studies have been conducted in eelgrass beds of southern Korean waters. Of those, the focus was limited to only fish communities [25,32,40]. Studies on the effects on decapod diversity including assessment of bottom sediment structure, presence of seagrasses and hydrodynamic features including water temperature, tidal current and seasonal storms might provide key insight on factors influencing the maintenance decapod assemblages [41].

In this study, we compared decapod assemblages in seagrass beds adjacent to tidal flats and rocky shores with unvegetated habitats in structuring decapod assemblages. Our specific objectives were to 1) compare species richness, abundance, and diversity among habitats; and 2) associate differences in assemblage structures with habitat types, seasons, and day/night changes. Results from this study will contribute to a greater understanding of the dynamics between habitat complexity and the structure of decapod assemblages in Korean waters, promoting better resource conservation and management.

\section{Materials and Methods}

\subsection{Study area}

Investigations were conducted in a bay of Namhae Island and one of the adjacent Changseon-Do Island, southern Korea, with two study sites within each such bays (Figure 1). Bays comprised of a northern semi-enclosed (Dongdae Bay) and southern exposed (Aenggang Bay) body of water. Dongdae Bay faced inland and was surrounded by diverse geographic features such as tidal flats, rocky shores, small islands and reefs, whereas Aenggang Bay was exposed to open ocean from a southern inlet, allowing seawater circulation to the bay. The two study sites in each bay were seagrass beds adjacent to tidal flats (DT) and to rocky shore (DR) at Dongdae Bay, and seagrass beds (AS) and unvegetated habitat (AU) at Aenggang Bay (Figure 1). Dongdae Bay sediment composition consisted of compact particles (e.g. clay-silt). Sediment at Aenggang Bay, converselty, comprised of mostly coarse particles (Kim et al., unpublished data). Seagrass beds from both bays are characterized by Zostera marina, forming subtidal bands (2.7-3.3 $\mathrm{km}$ in width) along the shoreline in shallow water $(<5 \mathrm{~m})$. Seagrass biomass fluctuate with season peaking during spring, and seagrass density. Biomass is typically five times higher at Dongdae Bay than at Aenggang Bay [34]. Typical 
water temperatures ranged from $7.4{ }^{\circ} \mathrm{C}$ to $27.7{ }^{\circ} \mathrm{C}$ at Dongdae Bay and from $7.7{ }^{\circ} \mathrm{C}$ to $30.7{ }^{\circ} \mathrm{C}$ at Aenggang Bay. Salinity ranged from 19.5 to 34.2 psu at Dongdae Bay and from 16.5 to 34.8 psu at Aenggang Bay, with the lowest values during summer at both bays [34].

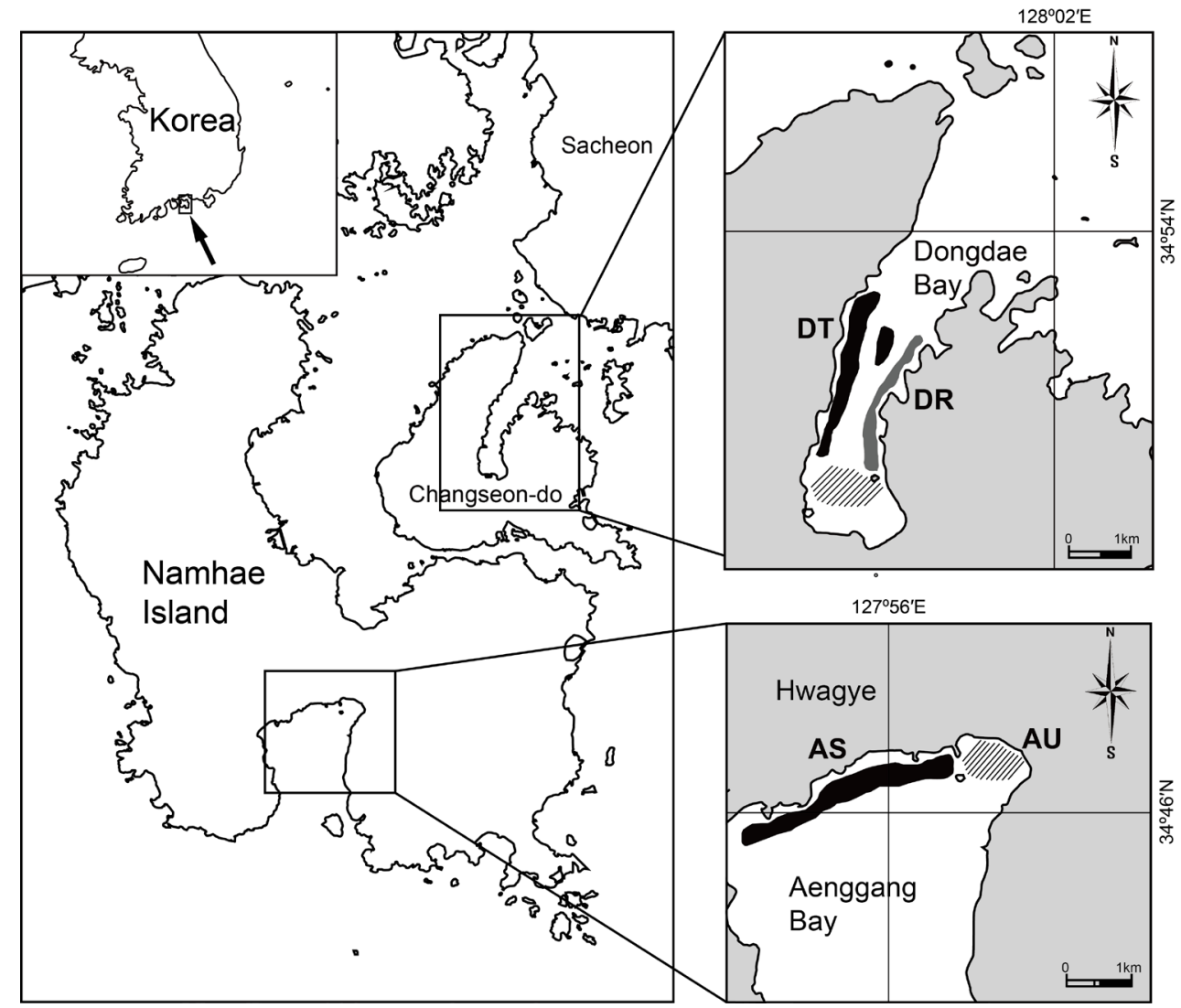

Figure 1. Location of study areas in Namhae Island, southern Korea. Black area = seagrass bed adjacent tidal flat (DT, AS), gray area = seagrass bed adjacent rocky shore (DR), oblique area = unvegetated site (AU).

\subsection{Sampling}

Crustacean decapod samples were collected monthly in 2005 using a $3 \mathrm{~m}$ beam trawl with $1.9-\mathrm{cm}$ mesh wing and body, and a $0.6-\mathrm{cm}$ mesh liner. Four 6-min tows per sampling were conducted during both day (between 10:00h and 12:00h) and night (between 20:00h and 22:00h) at spring tide in all habitats. The estimated coverage area was approximately $180 \mathrm{~m} 2$ at each sampling event. Decapod abundance was expressed as the number of individuals per $100 \mathrm{~m} 2$. Immediately after capture, individual decapods were preserved in 5\% formalin with seawater and later transferred to $70 \%$ ethanol for long-term storage. In the laboratory, specimens were identified to the species and weighed to the nearest milligram. All scientific names were checked against SeaLifeBase [42].

\subsection{Data analyses}

The Shannon-Wiener index ( $\mathrm{H}^{\prime}$; [43]) was used to estimate community-level diversity. Three-way analyses of variance (ANOVAs) were used to assess spatial and temporal differences in species richness (number of species), abundance (number of individuals), and diversity. The Shannon-Weiner index was the response variable. Habitat type, season, and day/night were fixed factors, with Tukey's HSD test for post-hoc ANOVA comparisons. All species were considered in the analyses, and abundances were $\log (\mathrm{x}+1)$-transformed. Four seasons were winter 
(December-February), spring (March-May), summer (June-August) and autumn (September-November).

Inferential and descriptive analyses were performed to further assess abundance trends with diel patterns, seasons, and habitat. Permutation multivariate analyses of variance (PERMANOVA) on $\log ($ abundance +1$)$ based on Bray-Curtis similarity matrices was conducted [44]. Analysis factors for the PERMANOVA were habitat (DT, AR, AS, and AU), season (factors winter, spring, summer, and autumn), and diel effects (day/night). Similarity matrices were used in a three-way PERMANOVA to test for factor effects. To assess statistical significance among factor levels, a canonical analysis of principal coordinates (CAPs) was used [45]. The A metric multidimensional scaling (mMDS) ordination technique was used to visualize factor effects. The relative contributions of species to the observed differences were assessed using correlation coefficients for relationships between each factor and the canonical axis. Individual species with both correlations higher than 0.4 and total abundance larger than 1 percent were plotted on CAP axes 1 and 2 for additional visualization of results.

ANOVA was conducted using SYSTAT software (Systat version 18, SPSS Inc., Chicago, IL, USA), and multivariate analyses were performed using routines in the PRIMER v7 multivariate statistics package (www.primer-e.com) and the PERMANOVA+ add-on module [45,46]. The statistical significance level of 0.05 was used throughout analyses.

\section{Results}

3.1. Decapod species composition

Thirty-eight decapod species from 4 taxa were collected from the study areas (Table 1). The major taxa ranked by species number were Caridea (19 spp.), followed by Brachyura (13 spp.), Penaeoidea (4 spp.) and Sergestoidea (2 spp.). The highest number of species was at the Aenggang Bay seagrass bed (AS), and the lowest at the seagrass bed adjacent to the rocky shore at Dongdae Bay (DB). The greatest decapod abundance was recorded at the seagrass bed of Aengang Bay and the lowest at the unvegetated habitat of Aengang Bay (AU). Overall, the study areas were dominated by the Caridea genera of Eualus, Heptacarpus and Latreutes. The species with highest abundance at all study sites was Heptacarpus pandaloides, followed by Eualus leptognathus, Latreutes anoplonyx and La. laminirostris. Among decapods, Palaemon species was dominant at Dongdae Bay, and Crangon affinis and Portunus sanguinolentus dominant at Aengang Bay (Table 1). 
Table 1. Decapod species and total abundance (per $100 \mathrm{~m} 2$ ) in seagrass beds adjacent to tidal flat (DT) and rocky shore (DR) of Dongdae Bay, and seagrass beds (AS) and areas adjacent to the unvegetated habitats (AU) of Aenggang Bay, Namhae Island, southern Korea.

\begin{tabular}{|c|c|c|c|c|c|}
\hline \multirow[b]{2}{*}{ Taxa } & \multirow[b]{2}{*}{ Species name } & \multicolumn{2}{|c|}{ Dongdae Bay } & \multicolumn{2}{|c|}{ Aenggang Bay } \\
\hline & & DT & DR & AS & AU \\
\hline \multirow[t]{4}{*}{ Penaeoidea } & Metapenaeopsis tenella & 3.3 & 3.3 & 3.9 & 1.1 \\
\hline & Parapenaeopsis hardwickii & & 0.6 & & \\
\hline & Penaeus japonicus & & & 0.6 & \\
\hline & Trachysalambria curvirostris & 3.9 & & 0.6 & \\
\hline \multirow[t]{2}{*}{ Sergestoidea } & Acetes chinensis & 5.6 & & 1.7 & 3.9 \\
\hline & Acetes japonicus & 0.6 & & 0.6 & \\
\hline \multirow[t]{19}{*}{ Caridea } & Alpheus brevicristatus & 2.2 & & 0.6 & 1.1 \\
\hline & Alpheus digitalis & & 0.6 & 1.1 & \\
\hline & Crangon affinis & 1.7 & 2.2 & 76.7 & 92.8 \\
\hline & Crangon hakodatei & 0.6 & & 24.4 & 14.4 \\
\hline & Eualus leptognathus & $1,380.6$ & 544.4 & 347.2 & 9.4 \\
\hline & Eualus middendorffi & 3.9 & 1.7 & & \\
\hline & Hayashidonus japonicus & & & 7.8 & 3.3 \\
\hline & Heptacarpus futilirostris & 61.7 & 0.6 & 16.7 & 1.1 \\
\hline & Heptacarpus pandaloides & $2,462.2$ & 925.0 & $5,067.2$ & 882.2 \\
\hline & Heptacarpus rectirostris & 17.8 & 7.2 & 108.9 & 0.6 \\
\hline & Latreutes anoplonyx & 334.4 & 578.3 & $2,220.6$ & 106.1 \\
\hline & Latreutes laminirostris & 415.6 & 185.6 & 123.9 & 52.8 \\
\hline & Latreutes planirostris & 0.6 & & 3.3 & \\
\hline & Leptochela gracilis & & & 0.6 & \\
\hline & Lysmata vittata & & 0.6 & 0.6 & \\
\hline & Palaemon carinicauda & 1.1 & 1.7 & & \\
\hline & Palaemon macrodactylus & 224.4 & 46.7 & 4.4 & 5.6 \\
\hline & Palaemon orientis & 18.9 & 3.9 & & \\
\hline & Palaemon ortmanni & 92.8 & 30.6 & 40.0 & 8.3 \\
\hline \multirow[t]{13}{*}{ Brachyura } & Arcania undecimspinosa & & & & 0.6 \\
\hline & Charybdis japonica & 5.0 & 8.3 & 94.4 & 20.0 \\
\hline & Charybdis sagamiensis & & & 3.3 & \\
\hline & Hemigrapsus penicillatus & 20.0 & 11.1 & 6.1 & 0.6 \\
\hline & Hemigrapsus sanguineus & & & & 0.6 \\
\hline & Paradorippe granulata & & & 0.6 & \\
\hline & Pilumnus minutus & & 0.6 & & \\
\hline & Portunus sanguinolentus & 5.0 & & 28.9 & 2.8 \\
\hline & Portunus trituberculatus & & & 1.7 & 1.1 \\
\hline & Pugettia quadridens & 33.3 & 26.1 & 23.3 & 1.7 \\
\hline & Telmessus acutidens & 11.1 & 1.1 & 35.0 & 2.8 \\
\hline & Thalamita sima & & & 8.3 & 1.1 \\
\hline & Xanthidae sp. & 0.6 & & & \\
\hline & Total & $5,106.7$ & $2,380.0$ & $8,252.8$ & $1,213.9$ \\
\hline & umber of species & 25 & 21 & 30 & 23 \\
\hline
\end{tabular}




\subsection{Spatio-temporal changes in species richness, abundance, and diversity}

Mean species richness, abundance, and diversity varied by factors of habitat type, season, and diel patterns. Three-way ANOVA showed species richness and abundance of decapod assemblage differed significantly among habitats, seasons, and diel patterns. Diversity patterns were not significant for any factors (Table 2). No two-way or three-way interactions were significant between most factors. Only the habitat $\times$ season interaction for abundance was significant influence on decapod assemblage (Table 2).

Table 2. Three-way ANOVA on the number of species, their abundance (100m-2), and the diversity of decapod assemblages in the study areas. Bold letters indicate significant differences at $\mathrm{P} \leq 0.05$.

\begin{tabular}{cccccccc}
\hline & \multicolumn{3}{c}{ Species richness } & \multicolumn{2}{c}{ Abundance } & \multicolumn{2}{c}{ Diversity } \\
Source & df & F & P & F & P & F & P \\
\hline Main test & & & & & & & \\
Habitat (H) & 3 & 2.865 & $\mathbf{0 . 0 4 7}$ & 3.789 & $\mathbf{0 . 0 1 7}$ & 1.403 & 0.254 \\
Season (S) & 3 & 3.223 & $\mathbf{0 . 0 3 1}$ & 5.220 & $\mathbf{0 . 0 0 4}$ & 1.954 & 0.135 \\
Day/Night (D/N) & 1 & 4.780 & $\mathbf{0 . 0 3 4}$ & 4.513 & $\mathbf{0 . 0 3 9}$ & 1.627 & 0.209 \\
Interactions & & & & & & & \\
$\mathrm{H} \times \mathrm{S}$ & 9 & 1.355 & 0.237 & 2.175 & $\mathbf{0 . 0 4 2}$ & 1.203 & 0.317 \\
$\mathrm{H} \times \mathrm{D} / \mathrm{N}$ & 3 & 1.418 & 0.250 & 2.391 & 0.081 & 0.135 & 0.939 \\
$\mathrm{~S} \times \mathrm{D} / \mathrm{N}$ & 3 & 0.834 & 0.482 & 1.240 & 0.306 & 0.180 & 0.910 \\
$\mathrm{H} \times \mathrm{S} \times \mathrm{D} / \mathrm{N}$ & 8 & 0.397 & 0.916 & 0.863 & 0.554 & 0.405 & 0.912 \\
\hline
\end{tabular}

Tukey's post-hoc tests indicated that mean species richness was lower at unvegetated habitat and during summer (Figure 2). Mean abundance was the highest at seagrass beds in Aenggang Bay and during autumn, and lowest at unvegetated habitats and during summer (Figure 2). Diel patterns in decapod assemblage showed that both species richness and abundance was higher during night than day (Figure 2). However, there were no patterns in species diversity with all three factors combined (Figure 2). 

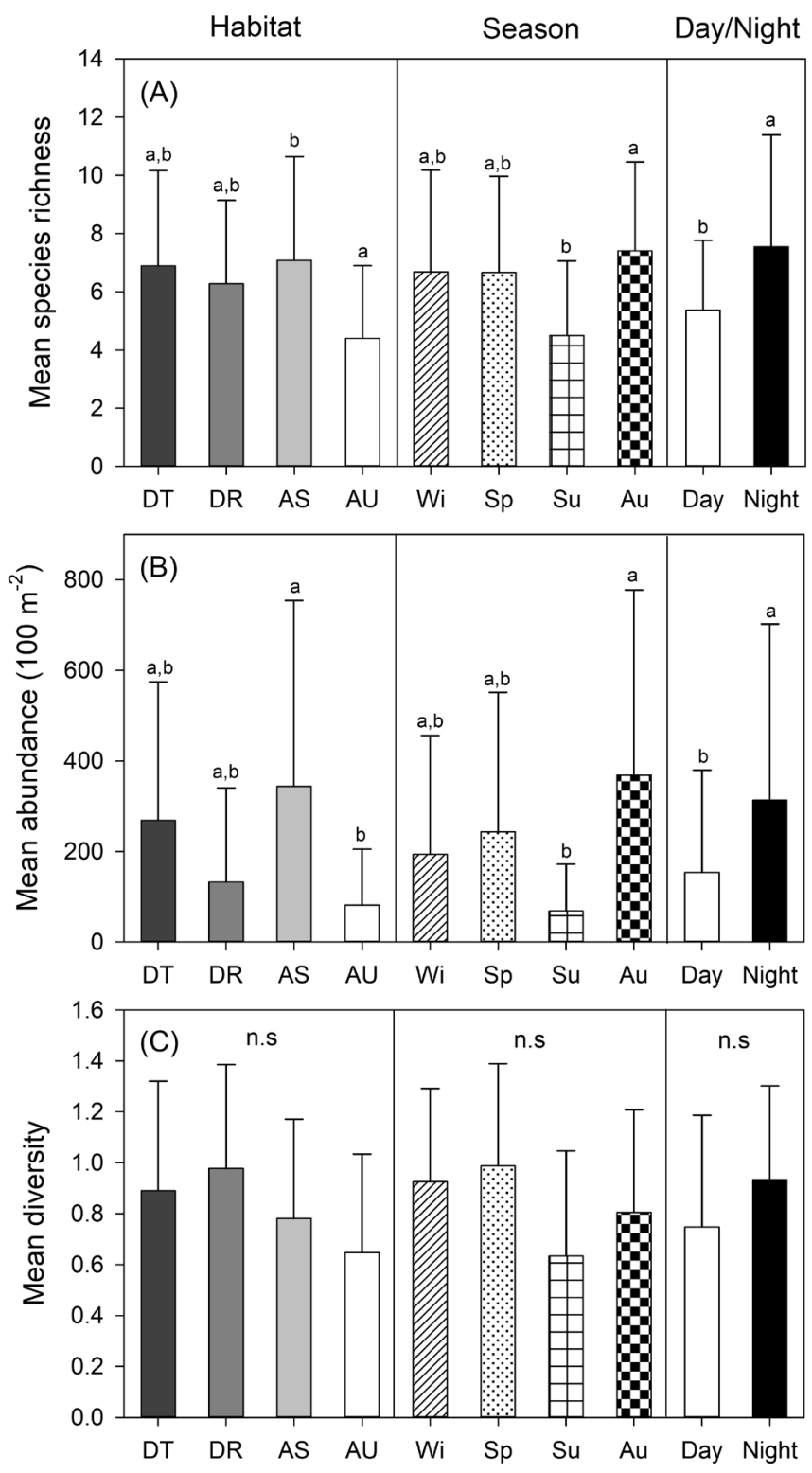

Figure 2. Variations in mean species richness (A), abundance (B), and diversity (C) of decapod assemblages with respect to habitat type, season, and diel patterns. Habitat are as in in Table 1 . Wi $=$ winter, $\mathrm{Sp}=$ spring, $\mathrm{Su}=$ summer, $\mathrm{Au}=$ autumn.

\subsection{Decapod assemblage structure}

Three-way PERMANOVA revealed decapod assemblages significantly associated with habitat type and season, with habitat and season being the strongest factors determining variation within samples (Table 3). Only a significant two-way interaction between habitat and season was observed (Table 3). Pairwise comparisons of habitat and season showed significant differences in decapod assemblage structures between Dongdae and Aenggang bays during spring, summer and autumn (Table 4). Significant differences between seasons within each habitat were also observed, except between winter and spring at all sites (Table 4). At Dongdae Bay, only differences between spring-summer at the DT habitat was significant. Seasonal comparisons between colder (winter and spring) and warmer (summer and autumn) seasons were significant at each of Aenggang Bay habitats (Table 4). 
Table 3. Mean squares (MS), pseudo-F ratios, and significance levels (P) for PERMANOVA tests using Bray-Curtis similarity matrices from abundance of decapod assemblages showing differences in habitat, site, season, and interactions terms; bold letters indicate significance at $\mathrm{P} \leq 0.05$.

\begin{tabular}{cccccc}
\hline Source & $\mathrm{df}$ & $\mathrm{MS}$ & Pseudo-F & $\mathrm{P}$ & $\mathrm{COV}$ \\
\hline Main test & & & & & \\
Habitat $(\mathrm{H})$ & 3 & 4749.6 & 4.2381 & $\mathbf{0 . 0 0 1}$ & 14.920 \\
Season $(\mathrm{S})$ & 3 & 4292.9 & 3.8306 & $\mathbf{0 . 0 0 1}$ & 13.902 \\
Day $/$ Night $(\mathrm{D} / \mathrm{N})$ & 1 & 1931.4 & 1.7234 & 0.096 & 5.212 \\
Interactions & & & & & \\
$\mathrm{H} \times \mathrm{S}$ & 9 & 1770.9 & 1.5802 & $\mathbf{0 . 0 1 9}$ & 12.227 \\
$\mathrm{H} \times \mathrm{D} / \mathrm{N}$ & 3 & 1902.8 & 1.6979 & 0.062 & 9.814 \\
$\mathrm{~S} \times \mathrm{D} / \mathrm{N}$ & 3 & 1496.2 & 1.3350 & 0.166 & 6.838 \\
$\mathrm{H} \times \mathrm{S} \times \mathrm{D} / \mathrm{N}$ & 8 & 996.9 & 0.8896 & 0.655 & -7.379 \\
Residual & 46 & 1120.7 & & & \\
\hline
\end{tabular}

Table 4. Pairwise PERMANOVA tests for the site-season interaction within each site, or season; bold letters indicate significance at $\mathrm{P} \leq 0.05$.

\begin{tabular}{|c|c|c|c|c|c|c|c|c|}
\hline \multirow[b]{2}{*}{ Station } & \multicolumn{2}{|c|}{ Winter } & \multicolumn{2}{|c|}{ Spring } & \multicolumn{2}{|c|}{ Summer } & \multicolumn{2}{|c|}{ Autumn } \\
\hline & $\mathrm{t}$ & $\mathrm{P}$ & $\mathrm{t}$ & $\mathrm{P}$ & $\mathrm{t}$ & $\mathrm{P}$ & $\mathrm{t}$ & $\mathrm{P}$ \\
\hline DT-DR & 0.607 & 0.875 & 1.265 & 0.256 & 0.866 & 0.614 & 1.341 & 0.188 \\
\hline DT-AS & 1.036 & 0.355 & 2.122 & 0.028 & 1.586 & 0.032 & 2.135 & 0.014 \\
\hline DT-AU & 1.247 & 0.212 & 2.047 & 0.018 & 2.024 & 0.008 & 1.689 & 0.037 \\
\hline DR-AS & 1.026 & 0.332 & 1.261 & 0.214 & 1.556 & 0.048 & 2.337 & 0.012 \\
\hline DR-AU & 1.846 & 0.167 & 1.168 & 0.260 & 1.646 & 0.053 & 1.591 & 0.074 \\
\hline \multirow[t]{2}{*}{ AS-AU } & 1.511 & 0.107 & 1.548 & 0.118 & 0.946 & 0.506 & 1.495 & 0.106 \\
\hline & \multicolumn{2}{|c|}{ DT } & \multicolumn{2}{|c|}{ DR } & \multicolumn{2}{|c|}{ AS } & \multicolumn{2}{|c|}{ AU } \\
\hline Season & $\mathrm{t}$ & $\mathrm{P}$ & $\mathrm{t}$ & $\mathrm{P}$ & $\mathrm{t}$ & $\mathrm{P}$ & $\mathrm{t}$ & $\mathrm{P}$ \\
\hline Winter-Spring & 1.357 & 0.183 & 0.799 & 0.592 & 1.197 & 0.238 & 1.064 & 0.394 \\
\hline Winter-Summer & 1.138 & 0.297 & 1.472 & 0.136 & 1.561 & 0.027 & 1.088 & 0.369 \\
\hline Winter-Autumn & 1.007 & 0.463 & 0.947 & 0.429 & 2.202 & 0.014 & 2.818 & 0.020 \\
\hline Spring-Summer & 2.183 & 0.008 & 0.783 & 0.623 & 1.186 & 0.224 & 1.501 & 0.029 \\
\hline Spring-Autumn & 1.411 & 0.157 & 0.788 & 0.654 & 2.567 & 0.012 & 2.074 & 0.013 \\
\hline Summer-Autumn & 1.259 & 0.189 & 0.601 & 0.831 & 2.140 & 0.004 & 2.113 & 0.007 \\
\hline
\end{tabular}

Metric MDS ordination of similarity of mean decapod assemblages showed a clear difference in decapod assemblages by habitat type and season (Figure 3). Samplings from different locations showed distinct clustering patterns, while the multivariate dispersions slightly overlapped habitats within each bay (Figure 3a). Taking seasonal data pooled by site also showed clear clustering. Bootstrap averages of samples between warmer seasons (i.e. summer and autumn) showed clear separation, compared with the average assemblages between colder seasons (Figure 3b). In addition, samples of seasonal decapod assemblage were clearly divided between warmer and colder seasons along with the $\mathrm{Y}$ axis in $\mathrm{mMDS}$ ordination. 

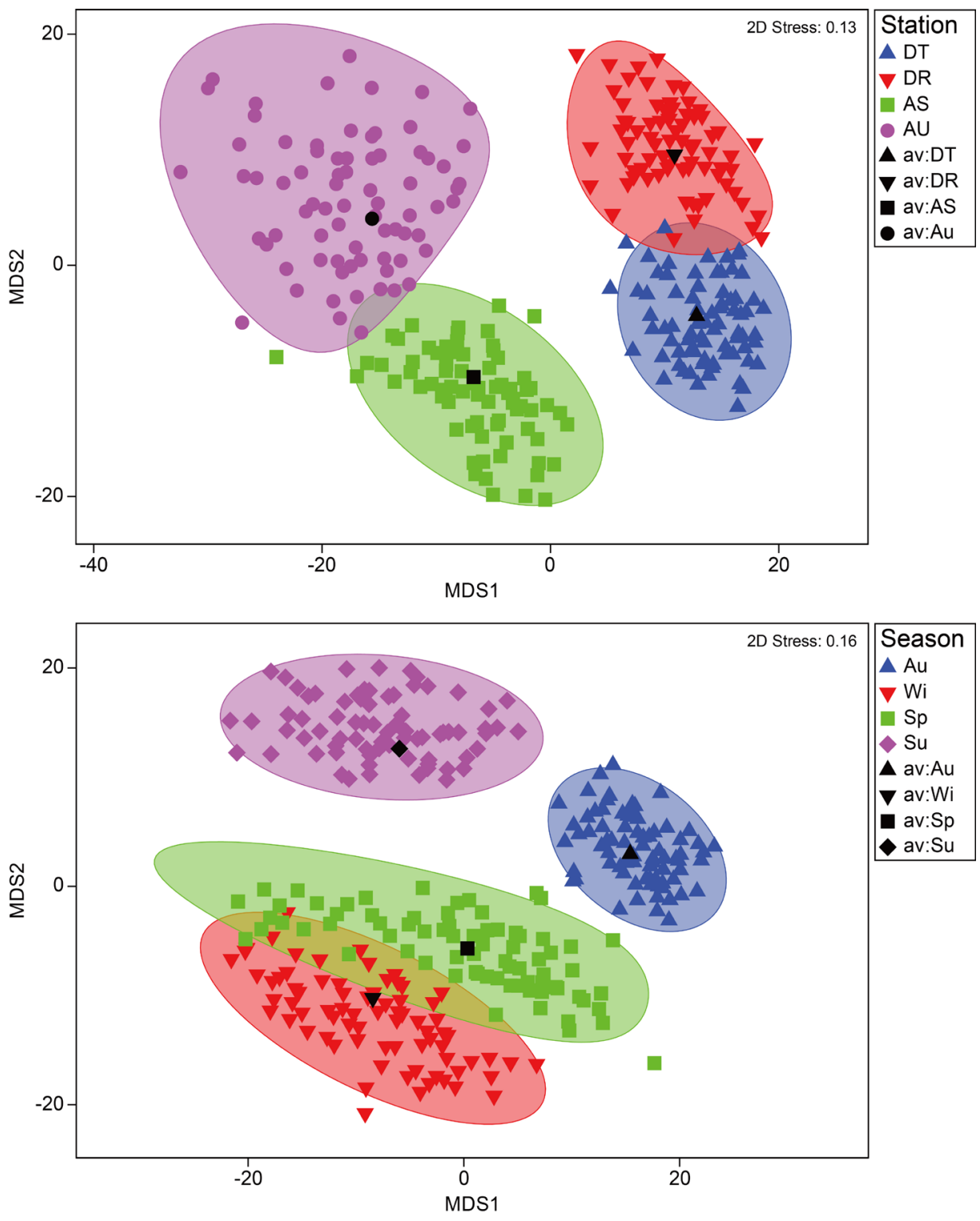

Figure 3. Metric MDS ordination of decapod assemblages constructed from Bray-Curtis similarity matrices of the four habitat types (A) and four seasons (B). Habitat codes are as shown in Table 1; season codes; $\mathrm{Wi}=$ winter, $\mathrm{Sp}=$ spring, $\mathrm{Su}=$ summer, $\mathrm{Au}=$ autumn.

To further investigate PERMANOVA results, CAP analyses were performed on significant interactions. The CAP plot for site-season interaction showed a clear separation among factor groups (Figure 4). Palaemon macrodactylus and Pugettia quadridens contributed to separate the sites of Dongdae Bay from those in Aenggang Bay. Telmessus acutidens, two crangonid shrimps (Cr. affinis and Cr. hakodatei) and two portunid crabs (Charybdis japonica and Portunus trituberculatus) characterized the decapod assemblages in Aenggang Bay (Figure 4). Weak seasonal differences in decapod assemblages were found at Dongdae Bay sites, although there were some trends on species contribution of $\mathrm{Pa}$. macrodactylus and $\mathrm{Pu}$. quadridens on colder and warmer season assemblages, respectively. Conversely, clear seasonal classifications in decapod assemblages were evident at Aenggang Bay sites. Te. acutidens and Cr. affinis contributed to the colder season samples, and Cr. hakodatei, Ch. japonica and Po. trituberculatus to the warmer season samples, regardless of habitat type (Figure 4). 


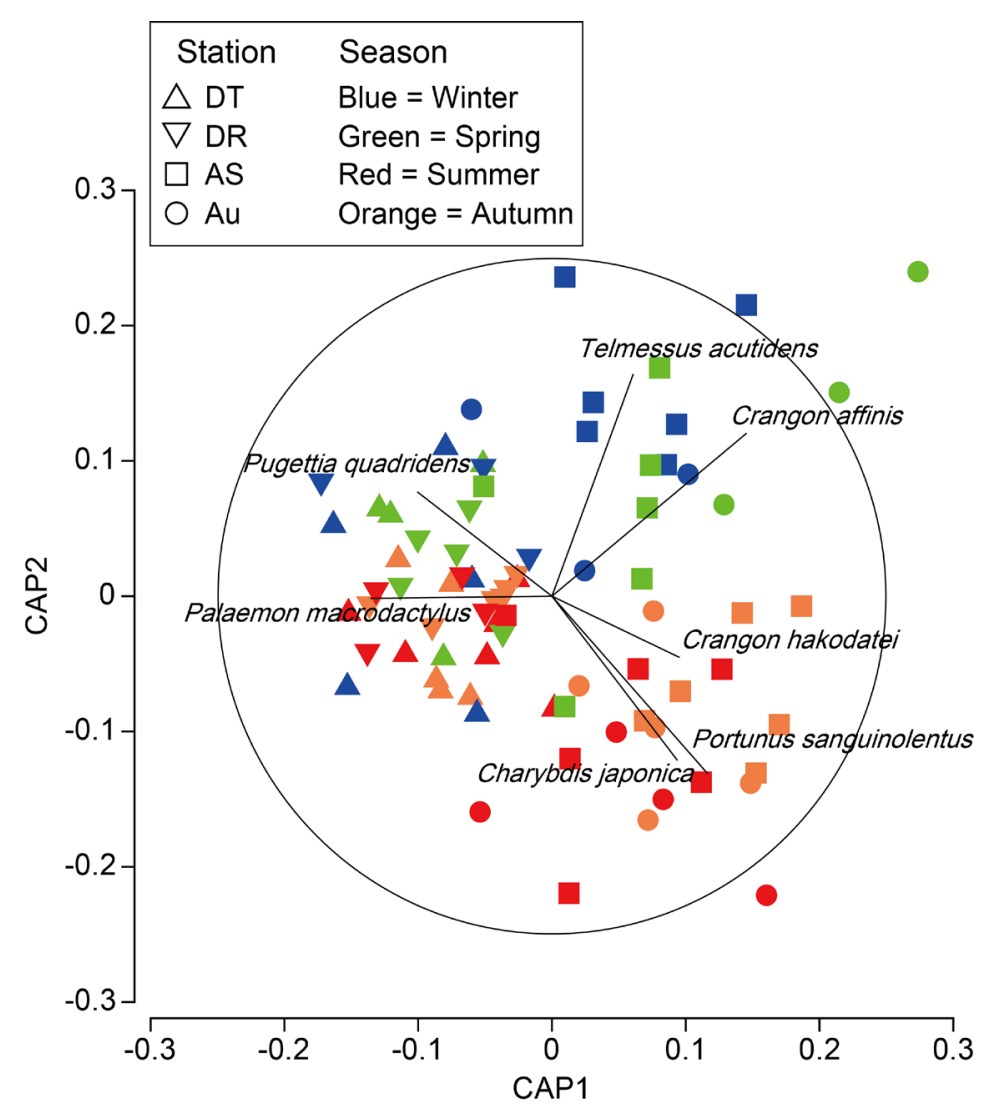

Figure 4. Canonical analysis of principal coordinates (CAP) ordination plots of decapod assemblages showing differences among habitat-season interaction terms; habitat codes were as shown in Table 1 caption.

\section{Discussion}

From the 38 species collected, the dominant caridean shrimps were Ha. pandaloides, La. anoplonyx, Eu. leptognathus, La. laminirostris, Pa. macrodactylus, and abundant crab species were Ch. japonica, Pu. quadridens, and Te. acutidens. Broad-scale surveys of decapod communities in seagrass beds from other regions of southern Korea have shown similar community structures. Heptacarpus, Latreutes, Eualus and Palaemon were the dominant shrimp genera at the seagrass beds in Kwang Bay and Jinhae Bay $[4,25,47]$. Charybdis japonica, Pu. quadridens, and Te. acutidens were the common crab species at the seagrass beds of Jinhae Bay, but they were not in adjacent unvegetated areas of the bay [25]. Compared with seagrass beds of temperate regions worldwide, the genera Eualus, Heptacarpus and Latreutes were the principally North Pacific carid genera often abundant in Zostera meadows [31] Crangon and Palaemon also dominated the decapod communities of seagrass beds in Western Port Bay, Australia [5,48]. Charybdis japonica and Pu. quadridens in particular were the seagrass dependent crab species in northwestern Pacific regions [49,50]. The above taxonomical groups, therefore, seem common decapods inhabiting seagrass beds of temperate Pacific regions, regardless of locations.

Seagrass beds are highly productive, showing higher abundances and diversity of marine organisms compared with unvegetated habitats (e.g. $[6,25,51])$. This is due to the higher capacity of seagrass vegetation in supporting large density and species richness of faunal assemblages [29]. This study corroborated the expected by showing higher abundance in seagrass beds. Species richness, however, did not show this pattern. Similarly, no significant differences in diversity were evident among habitat types. A number of studies have shown significantly higher decapod abundances at vegetated habitats (e.g., [24,25]). Park and Kwak [25] documented that decapod abundances within 
seagrass habitats were also significantly influenced by habitat structures associated with adjacent environments, where seagrass bed associated with vegetated tidal flats had a higher decapod abundance than seagrass beds adjacent to rocky shores or unvegetated habitats. Physical habitat structure (i.e. both seagrass vegetation and adjacent environment), therefore, is one of the main forces driving abundance of coastal marine animals in seagrass habitat [52].

High seagrass biomass has been shown indicative of high species richness and abundance of faunal assemblages in seagrass habitats (e.g., [25,53]), because increased seagrass biomass favors available space (micro-refuges) and food availability, as well as a decrease in predation [6,54]. Although marked differences were found in seagrass biomass between the two study bays, with Dongdae Bay having higher seagrass biomass than Aenggang Bay [34], species richness and abundance of decapod assemblages was not associated with seagrass density in the study area. Hori et al. [55] reported that extremely high seagrass biomass does not always correspond with high species richness, but intermediate seagrass biomass may more commonly lead to increased abundance of faunal communities. Moranta et al. [56] also demonstrated that larger and denser meadows hosted high numbers of small-sized fishes, but not larger adults. Thus, decapod assemblage among seagrass beds in this study may not be influenced solely by seagrass biomass, but other physical factors, such as shoreline characteristics can be another factor influencing decapod abundance. In the Cádiz Bay of southwestern Spain, inner bay habitats with higher vegetative cover and relatively limited water renewal supported lower species richness compared with the outer bay [57]. Similarly, in this study, exposure to open ocean likely supports increased habitat accessibility for marine animals, whereas protected or semi-enclosed bays allow only limited access. Ávila et al. [58] reported that the total number of macroinvertebrate species was relatively higher in semi-exposed and exposed seagrass beds than in protected seagrass beds. Thus, the effects of coastline patterns and meadow structure may interact, producing the patterns in decapod communities observed in this study.

Multivariate analyses confirmed that decapod assemblage structure differed significantly among habitat types and among seasons, especially between study locations (Dongday Bay and Aenggang Bay) and colder (winter and spring) and warmer (summer and autumn) seasons. Such a difference, however, was likely not only due to vegetative cover. The differences in assemblage may have also been caused by variations in habitat use of individual decapod species in different habitats and seasons. CAP analyses revealed that these differences were strongly associated with the contributions of several decapod groups to each habitat and each season. For example, Crangonidae shrimps were limited to Aenggang Bay, whereas Pu. quadridens and Pa. macrodactylus were highly associated with seagrass beds of Dongdae Bay. In this study, the differences of decapod assemblages are likely associated with sediment compositions (i.e. compact verse coarse particles), and degree of exposure to open sea between study locations [34]. Among decapod species, Crangonidae shrimps showed sediment preferences in coarse sand bottoms related to its borrowing ability $[59,60]$, whereas Palaemon species inhabited mainly seagrass covered beds [61,62] with mud bottoms [63]. De La Rosa et al. [57] also showed structures of decapod assemblages influenced by variability of granulometric composition in the Cádiz Bay, southwestern Spain, with low granulometric variability and fine sediment associated with structural heterogeneity. In addition, high circulation at exposed habitats (i.e., Anggang Bay) may allow accessibility for various marine species, including swimming crabs (Portunidae). Because each study site provided favorable habitats for those species, the differences in decapod assemblage may have come from different sediment structure and habitat exposures at each site. Nonetheless, several minor decapod groups including Eualus and Palaemon shrimps, Pu. quadridens and Te. acutidens consistently preferred vegetated habitats, regardless of geographical difference and sediment compositions.

Seasonal variation in both species richness and abundance was significant for seagrass decapod communities, with similar patterns among winter, spring and autumn, but considerably lower in the summer. The pattern observed was probably more due to stable and dense vegetative cover and less to hydrographic factors [41][64]. Decapod assemblages, however, were highly variable between 
colder and warmer seasons, especially at Aenggang Bay. This seasonal structural difference was mainly due to contributions of several crab species in each season; i.e. swimming crabs (Portunidae) were more associated with decapod assemblage during warmer season, while Telmessus acutidens contributed colder season assemblages. Spawning, coinciding with development of the seagrass, may have been the driver for the observed pattern [34,64,65], probably due to migration from deeper water to shallow habitat for reproduction. In addition, although two crangonid shrimps were highly associated with Aenggang Bay, their occurrence pattern between colder and warmer seasons was apparent for this bay. Such temporal segregations among sympatric species have also been reported for palaemonid shrimps, with varying freshwater inputs and salinity between dry and wet season in estuarine habitats [66], allowing coexistence of closely related species in a given habitat as a mechanism of temporal habitat and resource partitioning [67].

Overall species richness and abundance of decapods was higher at night than during the day. No significant diel patterns in assemblage structure, however, was evident. Decapod assemblage patterns in seagrass beds and shallow march creeks from sub-tropical and temperate estuaries have supported our observation (e.g. [29,31,68-70]). Diel differences in species richness and abundance might relate to diurnal changes in decapod behavior associated with variation in light intensity, turbidity, and tide [71,72]. Rountree and Able [68] reported that young-of-the-year decapod were significantly more abundant at night due to their nocturnal movement into shallow marsh creeks. From laboratory observations, Bauer [31] found that mean abundance of caridean shrimps from seagrass meadows were consistently higher at night, because of nocturnal emergence from daytime burrows. Several studies also reported nocturnal movement from substrate into the water column $[73,74]$, increasing abundance of epiphytic crustaceans at night in shallow seagrass habitats $[69,75]$. More recently, Hampel et al. [70] showed the densities of faunal assemblages influenced by the interplay of day-night difference and tidal cycle in an intertidal salt marsh creek, with the highest densities during low tide and night.

\section{Conclusions}

This study provides important insights into the spatio-temporal variabilities of decapod assemblages in seagrass beds and unvegetated areas from two locations at Namhae Island in southern Korean waters. Our findings show that decapod assemblage structure was significantly affected by habitat type, location, and season, driven principally by variations in the abundance of common decapod species. Moreover, decapod abundance was significantly higher in seagrass beds than in unvegetated habitats, and during night than day. Because seagrass habitats support a high abundance of ecologically and economically important marine organisms, preservation and management of such habitats must be a priority. Studies of faunal assemblages in seagrass habitats, such as this, establish important baselines for future research and management interventions toward marine biodiversity, areas where research is limited or lacking, as in southern Korean waters.

Author Contributions: All authors have read and agree to the published version of the manuscript. J.M.P.; methodology, validation, formal analysis and writing-original draft preparation, S.N.K. and R.R.; writing-review and editing.

Funding: This research was funded by the Korea Institute of Ocean Science \& Technology [grand numbers PE99713, PE99763].

Acknowledgments: We are grateful to Dr. Ha Won Kim and Mr. Bong Jun Seong for assistance with samplings and data analyses. Field surveys were conducted in accordance with the approval of "Research \& Training Fishery" in the Ministry of Ocean and Fisheries, Korea..

Conflicts of Interest: The authors declare no conflict of interest.

\section{References}


1. Thayer, G.; Wolfe, D.; Williams, R. The Impact of Man on Seagrass Systems: Seagrasses must be considered in terms of their interaction with the other sources of primary production that support the estuarine trophic structure before their significance can be fully appreciated. American Scientist 1975, 63, 288-296.

2. Duarte, C.M.; Marbà, N.; Gacia, E.; Fourqurean, J.W.; Beggins, J.; Barrón, C.; Apostolaki, E.T. Seagrass community metabolism: Assessing the carbon sink capacity of seagrass meadows. Global Biogeochemical Cycles 2010, 24.

3. Klumpp, D.; Howard, R.K.; Pollard, D. Trophodynamics and nutritional ecology of seagrass communities. In Biology of seagrasses, Larkum, A., McComb, A., Shepherd, S., Eds. 1989; pp. 394-437.

4. Huh, S.-H.; AN, Y.-R. Seasonal variation of shrimp (Crustacea: Decapoda) community in the eelgrass (Zostera marina) bed in Kwangyang Bay, Korea. Korean Journal of Fisheries and Aquatic Sciences 1997, 30, 532-542.

5. Connolly, R.; Jenkins, G.; Loneragan, N. Seagrass dynamics and fisheries sustainability. CSIRO Publishing: 1999.

6. Hemminga, M.A.; Duarte, C.M. Seagrass ecology; Cambridge University Press: 2000.

7. Blaber, S.; Brewer, D.; Salini, J. Fish communities and the nursery role of the shallow inshore waters of a tropical bay in the Gulf of Carpentaria, Australia. Estuarine, Coastal and Shelf Science 1995, 40, 177-193.

8. Beyst, B.; Hostens, K.; Mees, J. Factors influencing the spatial variation in fish and macrocrustacean communities in the surf zone of sandy beaches in Belgium. Journal of the Marine Biological Association of the United Kingdom 2002, 82, 181-187, doi:10.1017/S0025315402005337.

9. Nagelkerken, I.; Roberts, C.M.; Van der Velde, G.; Dorenbosch, M.; Van Riel, M.C.; Cocheret de la Morinière, E.; Nienhuis, P.H. How important are mangroves and seagrass beds for coral-reef fish? The nursery hypothesis tested on an island scale. Marine Ecology Progress Series 2002, 244, 299-305, doi:10.3354/meps244299.

10. Orth, R.J.; Heck, K.L.; van Montfrans, J. Faunal communities in seagrass beds: A review of the influence of plant structure and prey characteristics on predator-prey relationships. Estuaries 1984, 7, 339-350, doi:10.2307/1351618.

11. Edgar, G.J.; Shaw, C. The production and trophic ecology of shallow-water fish assemblages in southern Australia I. Species richness, size-structure and production of fishes in Western Port, Victoria. Journal of Experimental Marine Biology and Ecology 1995, 194, 53-81.

12. Guidetti, P.; Bussotti, S. Fish fauna of a mixed meadow composed by the seagrasses Cymodocea nodosa and Zostera noltii in the Western Mediterranean. Oceanologica Acta 2000, 23, 759-770.

13. Nelson, W. The role of predation by decapod crustaceans in seagrass ecosystems. Kiel. Meeresforsch 1981, 5, 529-536.

14. Polte, P.; Asmus, H. Influence of seagrass beds (Zostera noltii) on the species composition of juvenile fishes temporarily visiting the intertidal zone of the Wadden Sea. Journal of Sea Research 2006, 55, 244-252, doi:10.1016/j.seares.2005.11.004.

15. Orth, R. The importance of sediment stability in seagrass communities. In Ecology of marine benthos, Coull, B., Ed. University of South Carolina Press: Columbia, SC, 1977; pp. 281-300.

16. Wells, F.; Rose, R.; Lang, S. An analysis of benthic marine invertebrate communities in subtidal seagrass and sand habitats in Shark Bay, Western Australia. Records of the Western Australian Museum $1985,12,47-56$. 
17. Boström, C.; Mattila, J. The relative importance of food and shelter for seagrass-associated invertebrates: a latitudinal comparison of habitat choice by isopod grazers. Oecologia 1999, 120, $162-170$

18. Heck Jr, K.; Wetstone, G. Habitat complexity and invertebrate species richness and abundance in tropical seagrass meadows. Journal of Biogeography 1977, 4, 135-142.

19. Huston, M.A. Biological diversity: the coexistence of species; Cambridge University Press: 1994.

20. Blanchet, H.; de Montaudouin, X.; Lucas, A.; Chardy, P. Heterogeneity of macrozoobenthic assemblages within a Zostera noltii seagrass bed: diversity, abundance, biomass and structuring factors. Estuarine, Coastal and Shelf Science 2004, 61, 111-123.

21. Gratwicke, B.; Speight, M. The relationship between fish species richness, abundance and habitat complexity in a range of shallow tropical marine habitats. Journal of Fish Biology 2005, 66, 650-667.

22. Hull, S.L. Seasonal changes in diversity and abundance of ostracods on four species of intertidal algae with differing structural complexity. Marine Ecology Progress Series 1997, 161, 71-82.

23. May, R.M. Will a large complex system be stable? Nature 1972, 238, 413-414, doi:10.1038/238413a0.

24. Bloomfield, A.; Gillanders, B. Fish and invertebrate assemblages in seagrass, mangrove, saltmarsh, and nonvegetated habitats. Estuaries 2005, 28, 63-77.

25. Park, J.M.; Kwak, S.N. Seasonal and habitat structures of crustacean decapod assemblages associated with Zostera marina beds in northern Jinhae Bay, Korea. Journal of the Marine Biological Association of the United Kingdom 2019, 99, 461-471, doi:10.1017/S002531541800005X.

26. Jelbart, J.E.; Ross, P.M.; Connolly, R.M. Fish assemblages in seagrass beds are influenced by the proximity of mangrove forests. Marine Biology 2007, 150, 993-1002.

27. Mazumder, D.; Saintilan, N.; Williams, R.J. Fish assemblages in three tidal saltmarsh and mangrove flats in temperate NSW, Australia: A comparison based on species diversity and abundance. Wetlands Ecology and Management 2006, 14, 201-209, doi:10.1007/s11273-005-7887-4.

28. Lazzari, M.A. Epibenthic fishes and decapod crustaceans in northern estuaries: A comparison of vegetated and unvegetated habitats in Maine. Estuaries 2002, 25, 1210-1218, doi:10.1007/bf02692218.

29. Krumme, U. Diel and tidal movements by fish and decapods linking tropical coastal ecosystems. In Ecological connectivity among tropical coastal ecosystems, Springer: 2009; pp. 271-324.

30. Gray, C.; Chick, R.; McElligott, D. Diel changes in assemblages of fishes associated with shallow seagrass and bare sand. Estuarine, Coastal and Shelf Science 1998, 46, 849-859.

31. Bauer, R.T. Diel and seasonal variation in species composition and abundance of caridean shrimps (Crustacea, Decapoda) from seagrass meadows on the north coast of Puerto Rico. Bulletin of Marine Science 1985, 36, 150-162.

32. Huh, S.H.; Kwak, S.N. Species composition and seasonal variations of fishes in eelgrass (Zostera marina) bed in Kwangyang Bay. Korean Journal of Ichthyology 1997, 9, 202-220.

33. Yun, S.G.; Huh, S.H.; Kwak, S.N. Species composition and seasonal variations of benthic macrofauna in eelgrass, Zostera marina, bed. Korean Journal of Fisheries and Aquatic Sciences 1997, 30, 744-752.

34. Park, J.M.; Kwak, S.N. Seagrass fish assemblages in the Namhae Island, Korea: The influences of seagrass vegetation and biomass. Journal of Sea Research 2018, 139, 41-49, doi:10.1016/j.seares.2018.06.007.

35. Bell, J.D.; Westoby, M. Importance of local changes in leaf height and density to fish and decapods associated with seagrasses. Journal of Experimental Marine Biology and Ecology 1986, 104, 249-274. 
36. Heck, K.; Able, K.; Fahay, M.; Roman, C. Fishes and decapod crustaceans of Cape Cod eelgrass meadows: species composition, seasonal abundance patterns and comparison with unvegetated substrates. Estuaries 1989, 12, 59-65.

37. Worthington, D.G.; Ferrell, D.J.; McNeill, S.E.; Bell, J.D. Effects of the shoot density of seagrass on fish and decapods: are correlation evident over larger spatial scales? Marine Biology 1992, 112, 139-146, doi:10.1007/BF00349737.

38. Sanchez-Jerez, P.; Barbera-Cebrian, C.; Ramos-Espla, A.A. Influence of the structure of Posidonia oceanica meadows modified by bottom trawling on crustacean assemblages: Comparison of amphipods and decapods. Scientia Marina 2000, 64, 319-326, doi:10.3989/scimar.2000.64n3319.

39. Kwak, S.N.; Klumpp, D.W. Temporal variation in species composition and abundance of fish and decapods of a tropical seagrass bed in Cockle Bay, North Queensland, Australia. Aquatic Botany 2004, 78, 119-134, doi:10.1016/j.aquabot.2003.09.009.

40. Kwak, S.N.; Huh, S.H.; Kim, H.W. Change in fish assemblage inhabiting around Dae Island in Gwangyang Bay, Korea. Journal of the Korean Society of Marine Environment E Safety 2012, 18, 175-184.

41. De La Rosa, I.L.; Rodríguez, A.; Raso, J.E.G. Seasonal variation and structure of a decapod (Crustacea) assemblage living in a Caulerpa prolifera meadow in Cadiz Bay (SW Spain). Estuarine Coastal and Shelf Science 2006, 66, 624-633, doi:10.1016/j.ecss.2005.11.008.

42. Palomares, M.; Pauly, D. SeaLifeBase. World Wide Web electronic publication. Availabe online: www.sealifebase.org (accessed on

43. Shannon, C.; Weaver, W. The Mathematical Theory of Communication; Illinois University Press: Urbana, 1949.

44. Clarke, K.R.; Somerfield, P.J.; Chapman, M.G. On resemblance measures for ecological studies, including taxonomic dissimilarities and a zero-adjusted Bray-Curtis coefficient for denuded assemblages. Journal of Experimental Marine Biology and Ecology 2006, 330, 55-80, doi:10.1016/j.jembe.2005.12.017.

45. Anderson, M.; Gorley, R.; Clarke, K. PERMANOVA+ for PRIMER: Guide to software and statistical methods; PRIMER-E Plymouth Marine Laboratory: Plymouth, UK, 2008.

46. Clarke, K.; Gorley, R. PRIMER v7: User Manual/Tutorial; PRIMER-E: Plymouth, UK, 2015.

47. Huh, S.-H.; An, Y.-R. Seasonal variation of crab (Crustacea: Decapoda) community in the eelgrass (Zostera marina) bed in Kwangyang Bay, Korea. Korean Journal of Fisheries and Aquatic Sciences 1998, 31, 535-544.

48. Howard, R.K. The trophic ecology of caridean shrimps in an eelgrass community. Aquatic Botany 1984, $18,155-174$.

49. Xu, Q.; Guo, D.; Zhang, P.D.; Zhang, X.M.; Li, W.T.; Wu, Z.X. Seasonal variation in species composition and abundance of demersal fish and invertebrates in a Seagrass Natural Reserve on the eastern coast of the Shandong Peninsula, China. Chinese Journal of Oceanology and Limnology 2016, 34, 330-341, doi:10.1007/s00343-015-4323-3.

50. Watanabe, Y.; Kawamura, T.; Yamashita, Y. Introduction: the coastal ecosystem complex as a unit of structure and function of biological productivity in coastal areas. Fisheries Science 2018, 84, 149-152, doi:10.1007/s12562-018-1176-7.

51. Bell, J. Ecology of fish assemblages and fisheries associated with seagrasses. Biology of Seagrasses 1989, 536-564. 
52. Guidetti, P. Differences among fish assemblages associated with nearshore Posidonia oceanica seagrass beds, rocky-algal reefs and unvegetated sand habitats in the Adriatic Sea. Estuarine, Coastal and Shelf Science 2000, 50, 515-529.

53. Klumpp, D.W.; Kwak, S.N. Composition and abundance of benthic macrofauna of a tropical sea-grass bed in north Queensland, Australia. Pacific Science 2005, 59, 541-561, doi:10.1353/psc.2005.0046.

54. Stoner, A. The role of seagrass biomass in the organization of benthic macrofaunal assemblages. Bulletin of Marine Science 1980, 30, 537-551.

55. Hori, M.; Suzuki, T.; Monthum, Y.; Srisombat, T.; Tanaka, Y.; Nakaoka, M.; Mukai, H. High seagrass diversity and canopy-height increase associated fish diversity and abundance. Marine Biology 2009, 156, 1447-1458.

56. Moranta, J.; Palmer, M.; Morey, G.; Ruiz, A.; Morales-Nin, B. Multi-scale spatial variability in fish assemblages associated with Posidonia oceanica meadows in the Western Mediterranean Sea. Estuarine, Coastal and Shelf Science 2006, 68, 579-592, doi:10.1016/j.ecss.2006.03.008.

57. De La Rosa, I.L.; Raso, J.G.; Rodríguez, A. Evolution of a decapod community (Crustacea) of shallow soft bottoms with seaweeds from southern Europe. Journal of the Marine Biological Association of the United Kingdom 2002, 82, 85-95.

58. Ávila, E.; Yáñez, B.; Vazquez-Maldonado, L.E. Influence of habitat structure and environmental regime on spatial distribution patterns of macroinvertebrate assemblages associated with seagrass beds in a southern Gulf of Mexico coastal lagoon. Marine Biology Research 2015, 11, 755-764, doi:10.1080/17451000.2015.1007875.

59. Pinn, E.H.; Ansell, A.D. The effect of particle size on the burying ability of the brown shrimp Crangon crangon. Journal of the Marine Biological Association of the United Kingdom 1993, 73, 365-377, doi:10.1017/S0025315400032926.

60. Ouellette, C.; Boghen, A.D.; Courtenay, S.C.; St-Hilaire, A. Influence of peat substrate on the distribution and behaviour patterns of sand shrimp, Crangon septemspinosa, under experimental conditions. Journal of Applied Ichthyology 2003, 19, 359-365, doi:10.1046/j.0175-8659.2003.00498.x.

61. Berglund, A. Niche differentiation between two littoral prawns in Gullmar Fjord, Sweden: Palaemon adspersus and P. squilla. Ecography 1980, 3, 111-115.

62. Baden, S.P.; Pihl, L. Abundance, biomass and production of mobile epibenthic fauna in Zostera marina (L.) meadows, western Sweden. Ophelia 1984, 23, 65-90.

63. Berglund, A.; Bengtsson, J. Biotic and abiotic factors determining the distribution of two prawn species: Palaemon adspersus and P. squilla. Oecologia 1981, 49, 300-304.

64. Yu, C.; Song, H.; Yao, G. The quantity distribution and biological property of Charybdis japonica in the East China Sea. Journal of Shanghai Fisheries University 2005, 14, 40-45.

65. Rasheed, S.; Mustaquim, J. Size at sexual maturity, breeding season and fecundity of three-spot swimming crab Portunus sanguinolentus (Herbst, 1783) (Decapoda, Brachyura, Portunidae) occurring in the coastal waters of Karachi, Pakistan. Fisheries Research 2010, 103, 56-62, doi:10.1016/j.fishres.2010.02.002.

66. McCarthy, L.C.; Loftus, W.F.; Rehage, J.S. Segregation of palaemonid shrimp along an Everglades estuarine gradient: Do multiple species have similar trophic function? Bulletin of Marine Science 2012, 88, 843-861, doi:10.5343/bms.2011.1058. 
67. Hamrin, S.F. Vertical distribution and habitat partitioning between different size classes of vendace, Coregonus albula, in thermally stratified lakes. Canadian Journal of Fisheries and Aquatic Sciences 1986, 43, 1617-1625.

68. Rountree, R.A.; Able, K.W. Diel variation in decapod crustacean and fish assemblages in New Jersey polyhaline marsh creeks. Estuarine, Coastal and Shelf Science 1993, 37, 181-201, doi:10.1006/ecss.1993.1050.

69. Guest, M.A.; Connolly, R.M.; Loneragan, N.R. Seine nets and beam trawls compared by day and night for sampling fish and crustaceans in shallow seagrass habitat. Fisheries Research 2003, 64, 185-196.

70. Hampel, H.; Cattrijsse, A.; Vincx, M. Tidal, diel and semi-lunar changes in the faunal assemblage of an intertidal salt marsh creek. Estuarine, Coastal and Shelf Science 2003, 56, 795-805.

71. Dall, W.; Hill, B.; Rothlisberg, P.; Sharples, D. The Biology of the Penaeidae; Academic Press: 1990; Vol. 27, pp. 1-489.

72. Breckenridge, J.K.; Bollens, S.M. Vertical distribution and migration of decapod larvae in relation to light and tides in Willapa Bay, Washington. Estuaries and Coasts 2011, 34, 1255-1261, doi:10.1007/s12237-011-9405-7.

73. Robertson, A.I.; Howard, R.K. Diel trophic interactions between vertically-migrating zooplankton and their fish predators in an eelgrass community. Marine Biology 1978, 48, 207-213, doi:10.1007/BF00397146.

74. Robertson, A.; Klumpp, D. Feeding habits of the southern Australian garfish Hyporhamphus melanochir: A diurnal herbivore and nocturnal carnivore. Marine Ecology Progress Series 1983, 10, 197-201.

75. Unsworth, R.K.F.; Wylie, E.; Smith, D.J.; Bell, J.J. Diel trophic structuring of seagrass bed fish assemblages in the Wakatobi Marine National Park, Indonesia. Estuarine, Coastal and Shelf Science 2007, 72, 81-88, doi:10.1016/j.ecss.2006.10.006. 